(CD45RA+) among cytotoxic and $\mathrm{T}$ helper cells; $\mathrm{T}$ regulatory cells (CD4 +CD25highCD127low); B1 cells (CD45+CD19+CD5+).

Results: We found that analyzed cell populations differ significantly in the co-expression of type 1 and 2 receptors for TNF $\alpha$ both between each other and compared to healthy donors. The most pronounced differences between groups of patients in the expression profile were shown for B cells, $\mathrm{T}$ reg and memory cells (figure).

The total proportion of cells with at least one type of receptors was significantly decreased as compared with HD (in the case of B cells, Thelper memory cells) or increased (in the case of naive cytotoxic $\mathrm{T}$ cells, naïve $T$ helper cells, monocytes, $T$ regs). This indicator may reflect the overall sensitivity of the cells of the subpopulation to the effects of cytokine. This mechanism may reflect the ability of the cells to react on certain TNF-alpha concentration or anti-cytokine therapy.

Conclusion: The profile of TNFR112 co-expression is changed in RA compared to heath. RA disease activity is associated with the changes in the amount and co-expression of type 1 and type 2 receptors for TNF-alpha on the surface of immunocompetent cells.
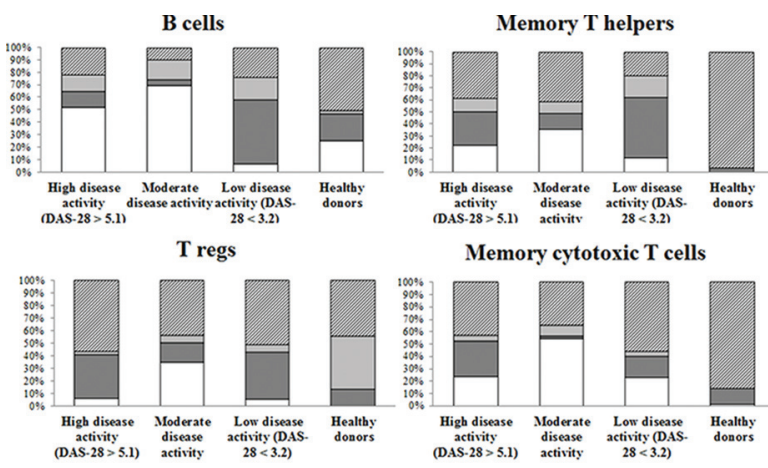

$\square$ Double-negative $\square$ Double-positive $\square$ TNFR1 only $\quad$ TTNFR2 only

Disclosure of Interests: None declared

DOI: 10.1136/annrheumdis-2019-eular.6575

\section{SAT0075 FACTORS ASSOCIATED TO DEVELOPING CVD AND STROKE IN PATIENTS WITH ESTABLISHED RHEUMATOID ARTHRITIS- A BARFOT COHORT STUDY}

loana Filip ${ }^{1}$, Stefan Bergman ${ }^{2,3}$, Maria Andersson ${ }^{2,4}$, BARFOT study group. ${ }^{1}$ Capio Movement, Department od Rheumatology, Halmstad, Sweden; ${ }^{2} \mathrm{FoU}$ Spenshult, Halmstad, Sweden; ${ }^{3}$ Primary Health Care Unit, Department of Public Health and Community Medicine, Institute of Medicine, The Sahlgrenska Academy, University of Gothenburg, Gothenburg, Sweden; ${ }^{4}$ Lund University, Department of Clinical Sciences, Department of Rheumatology, Lund, Sweden

Background: Patients with rheumatoid arthritis (RA) have a higher risk of cardiovascular diseases (CVD) and stroke. More knowledge about associated factors is needed since it could have implications on different treatment strategies

Objectives: To study factors associated to CVD and stroke development in patients with established RA.

Methods: A questionnaire was sent twice to patients with established RA in the BARFOT cohort, in $2010(n=1525)$ and in 2017 ( $n=1046)$ with a response rate of $73 \%$ and $68 \%$ respectively. 950 patients responded to both questionnaires. All patients fulfilled the ACR criteria for classification of RA and had a disease duration at inclusion (1992 to 2006) of $\leq 12$ months. The patients reported body mass index, smoking habits, tender (TJC) and swollen joint count (SJC, 28-joints), pain intensity (NRS) and physical function (HAQ), health related QoL (EQ5D), and medical treatment (DMARD, corticosteroids and NSAID). Possible factors associated with developing CVD or stroke at the questionnaire in 2017 or not (dependent variable) was studied by using a logistic regression analysis. Results: Twenty-two patients (3\%) developed CVD and 55 (6\%) patients stroke over the seven years between the two questionnaires. Patients that developed CVD were older and to a higher rate men. They also more often, $40 \%$ vs. $11 \%, p=0.001$, reported treatment with corticosteroids at both questionnaires. In a multivariate regression analysis age, OR $(95 \%$ Cl) 1.071 (1.015-1.129), male gender 7.459 (2.664-20.883) and reporting treatment with corticosteroids at both questionnaires 4.473 (1.525-13.117) were associated to CVD. Patients that developed stroke were older and more often not treated with any DMARD, $30 \%$ vs. $18 \%$, $p=0.069$. There were no other significant differences between the groups. In a multivariate regression analysis age, OR $(95 \%$ Cl) 1.081 (1.047$1.117)$ and reporting treatment with conventional DMARD $0.510 \quad(0.259$ 1.004) were associated to stroke at the second questionnaire. There were no associations between reported use of NSAIDs and development of CVD or stroke in this study.

Conclusion: Knowledge about factors associated to cardiovascular disease is important when treating patients with established RA. Long-term treatment with corticosteroids seems to increase the risk to develop CVD Treatment with DMARDs, especially conventional DMARDs, seems to decrease the risk to develop stroke. There were no association between developing CVD or stroke and NSAIDs in this study.

Disclosure of Interests: None declared

DOI: 10.1136/annrheumdis-2019-eular.2961

\section{SAT0076 EARLY REMISSION IS ESSENTIAL TO PREDICT LONGTERM REMISSION. CLINICAL RESULTS OF THE BELGIAN CAP48 RA COHORT}

Tatiana Sokolova ${ }^{1}$, Aleksandra Avramovska ${ }^{2}$, Pascalis Sidiras ${ }^{3}$,

Sandra Kleimberg ${ }^{3}$, Stephanie Dierckx ${ }^{4}$, Laurent Meric de Bellefon ${ }^{5}$

Serge Schreiber ${ }^{6}$, Clio Ribbens ${ }^{7}$, Michel Malaise ${ }^{7}$, Maria Stoenoiu ${ }^{2}$, Silvana

DI Romana ${ }^{5}$, Valérie Badot ${ }^{8}$, Patrick Durez ${ }^{2}{ }^{1}$ Coordinator arthritis medical research CAP 48, supported by the RTBF, Brussels, Belgium; ${ }^{2}$ Rheumatology department, Cliniques universitaires Saint-Luc - Université catholique de Louvain Institut de Recherche Expérimentale et Clinique (IREC), Brussels, Belgium; ${ }^{3}$ Rheumatology department, Hôpital Erasme, Cliniques universitaires de Bruxelles, ULB, Brussels, Belgium; ${ }^{4}$ Rheumatology department, CHU UCL Namur, Yvoir, Belgium; ${ }^{5}$ Rheumatology Department, CHU Saint-Pierre, Brussels, Belgium; ${ }^{6}$ Rheumatology department, Hôpital de Jolimont, Jolimont, Belgium;

${ }^{7}$ Rheumatology department, CHU de Liège, Site du Sart Tilman, ULg, Liège, Belgium; ${ }^{8}$ Rheumatology department, CHU Brugmann, ULB, Brussels, Belgium

Background: Early therapeutic intervention is crucial for patients with early rheumatoid arthritis (ERA). The goal of remission is achievable in a proportion of ERA patients.

Objectives: To evaluate the rate of patients in remission at 6 months and to correlate the 3 year remission rate. To identify baseline characteristics differences between patients achieving remission or not, and to report the best remission composite criteria to be used in daily care.

Methods: The Belgian CAP48 cohort supported by the French speaking radiotelevision (RTBF) is a unique prospective observational study of patients less than 50 years old with a recent diagnosis of ERA. All patients are naïve to DMARDs therapy and were recruited in different rheumatologic centers in Brussels and Wallonia. At baseline and every 6 months, demographic, specific clinical evaluation, questionnaires and laboratory were completed and treatment was adapted according each physician decision.

Results: 207 RA patients from 16 centers were analysed (162 F, $45 \mathrm{M}$, mean age 36.0 years, $27.8 \%$ with baseline erosion, $62.3 \%$ with ACPA, $59.9 \%$ with $\mathrm{FR}$, mean HAQ 1.9 , mean DAS28-CRP 4.54, mean SDA 24.9 and mean CDAI 23.4) history) and a group of 106 patients followed up to 36 months. Clinical results are summarized in this Table.

\begin{tabular}{|l|l|c|c|c|c}
\hline & $\begin{array}{l}\text { DAS28- } \\
\text { CRP } \\
\text { mean }\end{array}$ & $\begin{array}{l}\text { SDAI } \\
\text { mean }\end{array}$ & $\begin{array}{l}\text { CDAI } \\
\text { mean }\end{array}$ & $\begin{array}{c}\text { Remission (DAS28-CRP } \\
\text { /SDAI/CDA/Boolean) } \\
\%\end{array}$ & $\begin{array}{c}\text { HAQ } \\
\text { mean }\end{array}$ \\
\hline $\begin{array}{l}\text { Baseline } \\
n=207\end{array}$ & $\begin{array}{l}4.54 \\
(1.15)\end{array}$ & 24.9 & 23.4 & & 1.09 \\
\hline $\begin{array}{l}\text { Months 6 } \\
n=207\end{array}$ & $\begin{array}{l}2.83 \\
(1.21)\end{array}$ & 10.3 & 9.7 & $49.3 / 29.0 / 25.1 / 21.7$ & 0.61 \\
\hline $\begin{array}{l}\text { Months 36 } \\
n=106\end{array}$ & $\begin{array}{l}2.47 \\
(1.11)\end{array}$ & 8.5 & 7.5 & $59.4 / 39.6 / 34.9 / 31.1$ & 0.52 \\
\hline
\end{tabular}

Correlation between early 6 months response and long-term remission at 36 moths was performed in 106 patients: 63 patients achieved DAS28CRP remission at 36 months versus 43 patients.

DAS28-CRP and SDAl composite remission criteria observed at 6 months could predict long-term remission observed at 36 months (Figure); with DAS28-CRP, SDAI and CDAI mean values statistically different $(p<$ 0.01 , test-t) between two group.

At baseline, the following parameters are similar in two groups "long term remission" and "no long term remission", respectively: age (34.3 vs 33.8 yrs); Female (76.2 vs $72.1 \%$ ); smoker (24.1 vs $34.2 \%$ ); ACPA positive (66.7 vs $62.8 \%$ ); mean DAS28-CRP (4.4 vs 4.7$)$; mean HAQ (1.0 vs $1.2)$; baseline $\mathrm{X}$-ray erosion (21.7 vs $39.5 \%$ ). 
The time for diagnosis and treatment initiation is statistically shorter in "long term remission" group compared to the "no remission group" (mean of 1.4 months vs 3.4 months; $p=0.042$ )

Additionally, global remission (DAS28-CRP $<2,6, \mathrm{HAQ}<0,5$ and no X-ray progression) was observed in $41.5 \%$ of the long term remission group. The majority of these patients $(79 \%)$ are treated with Methotrexate.

Conclusion: Early and long term remission is an achievable goal in our observational CAP 48 study cohort. Early diagnosis is critical in standard of care. At 6 months, DAS28-CRP and SDAl were the best remission criteria to predict long term remission.

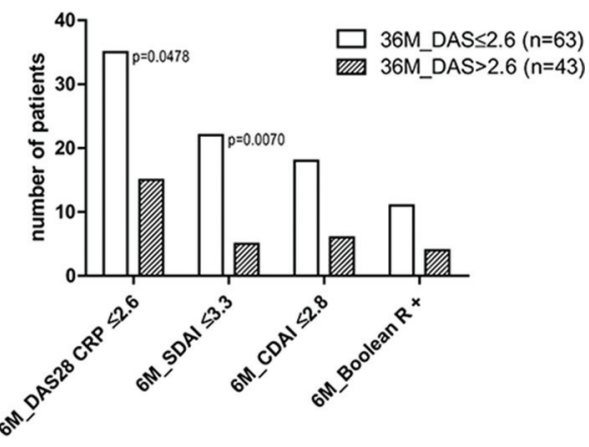

Acknowledgement: We are grateful to all participating investigators and clinical staffs which have made crucial contributions to the development of this Project.

Disclosure of Interests: Tatiana Sokolova: None declared, Aleksandra Avramovska: None declared, Pascalis Sidiras: None declared, Sandra Kleimberg: None declared, Stephanie Dierckx: None declared, Laurent Meric de Bellefon: None declared, Serge Schreiber: None declared, Clio Ribbens: None declared, Michel Malaise: None declared, Maria Stoenoiu Grant/research support from: Abbvie, Roche, Wyeth, Silvana Di Romana: None declared, Valérie Badot: None declared, Patrick Durez Speakers bureau: Bristol-Myers Squibb, Eli Lilly, Sanofi, Celltrion

DOI: 10.1136/annrheumdis-2019-eular.7069

\section{SAT0077 IMPACT OF THE COMBINED PRESENCE OF EROSIONS AND ACPA ON 6 AND 12 MONTHS CLINICAL OUTCOMES OF RHEUMATOID ARTHRITIS : RESULTS FROM THE METEOR REGISTRY}

Sytske Anne Bergstra ${ }^{1}$, Maura Couto ${ }^{2}$, Nimmisha Govind $^{3}$, Arvind Chopra ${ }^{4}$, Karen Solomon-Escoto ${ }^{5}$, Elizabeth Murphy ${ }^{6}$, Thomas Huizinga ${ }^{1}$, Cornelia Allaart ${ }^{1}$. ${ }^{1}$ LUMC, Leiden, Netherlands; ${ }^{2}$ Hospital Sao Teotónio, Viseu, Portugal; ${ }^{3}$ University of the Witwatersrand, Johannesburg, South Africa; ${ }^{4} \mathrm{CRD}$, Pune, India; ${ }^{5}$ University of Massachusetts/UMass Memorial MC, Worcester, United States of America; ${ }^{6}$ University Hospital Wishaw, Wishaw, United Kingdom

Background: Despite efforts to predict treatment response, treatment of rheumatoid arthritis (RA) patients remains mostly a case of trial and error. Presence of erosions and ACPA are often considered poor prognostic factors based on their association with radiographic damage progression, but with the introduction of treat-to-target ever fewer patients develop significant radiographic damage. Therefore research into prognostic factors should focus on clinical outcomes.

Objectives: To investigate in newly diagnosed RA patients if presence of erosions and/or ACPA are associated with functional ability, disease activity and treatment survival during the first year of treatment in daily practice.

Methods: Newly diagnosed patients with a clinical diagnosis of RA, $\geq 3$ months follow-up and available data on ACPA, erosions and medication were identified in the international, observational METEOR registry ( $n$ patients=4623). Timing and frequency of follow-up visits were according to daily practice. We focused at results after a maximum follow-up duration of 6 months or of 1 year from baseline. Associations between the presence of erosions and/or ACPA (4 groups) with the change of DAS and $H A Q$ over time were assessed using linear mixed models.

Time to treatment change during the first year of follow-up was compared between the ACPA/erosions groups using multiple failure-times Cox regression. Treatment change was defined as a change in type of treatment. A change in medication dose or tapering was not considered a treatment change.
Missing data were imputed using multiple chained equations (40 cycles) and models were adjusted for the potential confounders age, gender, smoking, symptom duration, BMI, initial medication and country. In case of statistically significant effect modification $(p<0.20)$ by country, medication group (csDMARD monotherapy, csDMARD combination therapy, csDMARD + glucocorticoid and other) or symptom duration group $(<1$ year, 1-2 years, 2-5 years and $>5$ years), results were stratified.

Results: Baseline characteristics and follow-up duration of each ACPA/erosions group are shown in table 1. Baseline DAS and $\mathrm{HAQ}$ were slightly higher in erosions+ patients. Follow-up duration was similar between the 4 groups. We found statistically significant differences in DAS and HAQ change over time between the 4 groups, both after maximum follow-up durations of 6 months and of 1 year (table 1), but differences were small and not clinically relevant.

Patients who were erosions-/ACPA- were less likely to switch treatment [HR $(95 \% \mathrm{Cl}) 0.79(0.69 ; 0.90)$ ] compared to a reference group of erosions-/ACPA+ patients. Patients who were erosions+/ACPA- $[\mathrm{HR}(95 \% \mathrm{Cl})$ $0.92(0.79 ; 1.08)]$ or erosions+/ACPA+ [HR (95\% Cl) $1.01(0.92 ; 1.10)]$ were not statistically significantly different from the reference group in their likelihood to switch treatment. No effect modification was found by country, medication or symptom duration.

Conclusion: In this analysis of worldwide real life data, we found statistically significant, but no clinically relevant differences in treatment response to initial DMARD therapies as measured by DAS and $H A Q$ in ACPA-/erosions-, ACPA-/erosions+, ACPA+/erosions- and ACPA+/erosions+ RA patients. However, ACPA-/erosions- patients were less likely to switch treatment. Thus, in newly diagnosed RA patients who are treated according to modern treatment strategies, the (combined presence of) ACPA and erosions was no risk factor for worse disease activity or physical functioning, although ACPA-/erosions- patients had fewer treatment changes.

\begin{tabular}{|c|c|c|c|c|c|}
\hline & & \multicolumn{2}{|c|}{ ACPA negative } & \multicolumn{2}{|c|}{ ACPA positive } \\
\hline & & $\begin{array}{c}\text { Erosions } \\
\text { negative } \\
n=701\end{array}$ & $\begin{array}{c}\text { Erosions } \\
\text { positive } \\
n=344\end{array}$ & $\begin{array}{l}\text { Erosions } \\
\text { negative } \\
n=1585\end{array}$ & $\begin{array}{l}\text { Erosions } \\
\text { positive } \\
n=1993\end{array}$ \\
\hline \multicolumn{2}{|l|}{ Female (\%) } & 83.0 & 83.4 & 81.4 & 84.9 \\
\hline \multicolumn{2}{|l|}{$\operatorname{RF}(\%$ positive) } & 31.0 & 33.5 & 93.0 & 95.3 \\
\hline \multirow[t]{3}{*}{ Smoking $(\%)$} & Never & 81.2 & 88.6 & 85.3 & 91.6 \\
\hline & Current & 7.3 & 4.7 & 9.3 & 5.2 \\
\hline & Stopped & 11.6 & 6.7 & 5.4 & 3.2 \\
\hline \multicolumn{2}{|c|}{ Age (years) mean (SD) } & $51(16)$ & $50(14)$ & $48(13)$ & $49(12)$ \\
\hline \multicolumn{2}{|c|}{ BMI mean (SD) } & $27.7(6.0)$ & $27.0(6.0)$ & $25.9(5.9)$ & $25.7(5.7)$ \\
\hline \multicolumn{2}{|c|}{$\begin{array}{l}\text { Symptom duration (months) } \\
\text { median (IQR) }\end{array}$} & $12(4-36)$ & $36(12 ; 72)$ & $18(6-48)$ & $48(19 ; 108)$ \\
\hline \multicolumn{2}{|c|}{ HAQ mean $(S D)$} & $0.98(0.61)$ & $1.1(0.6)$ & $0.88(0.59)$ & $1.1(0.6)$ \\
\hline \multicolumn{2}{|l|}{ DAS mean (SD) } & $3.5(0.93)$ & $4.0(1.0)$ & $3.6(0.97)$ & $4.0(0.95)$ \\
\hline \multirow{5}{*}{$\begin{array}{l}\text { ESR mean }(S D) \\
\text { Initial treatment } \\
(\%)\end{array}$} & & $47.5(32.8)$ & $60.1(37.8)$ & $65.5(36.0)$ & $72.8(36.0)$ \\
\hline & $\begin{array}{l}\text { CDMMARD } \\
\text { mono }\end{array}$ & 51.8 & 42.2 & 55.5 & 29.1 \\
\hline & $\begin{array}{l}\text { CSDMARD } \\
\text { Combi }\end{array}$ & 14.3 & 17.4 & 17.9 & 22.6 \\
\hline & $\begin{array}{l}\text { CSDMARD } \\
+G C\end{array}$ & 27.5 & 37.2 & 23.9 & 45.1 \\
\hline & Other & 6.43 & 3.2 & 2.7 & 3.2 \\
\hline \multicolumn{2}{|c|}{$\begin{array}{l}\text { Follow-up duration (months) } \\
\text { median (IQR) }\end{array}$} & $9.2(6.0 ; 10.6)$ & $8.8(6.0 ; 10.7)$ & $9.0(6.2 ; 10.6)$ & $9.3(6.7 ; 10.6)$ \\
\hline
\end{tabular}

sedimentation rate, mono $=$ monotherapy, combi $=$ combination the rapy, $G C=$ giucocorticoid.

Table 2. Associations between the presence of erosions and/Or ACPA on the change of DAS and HAQ

\begin{tabular}{|c|c|c|c|c|}
\hline & $\begin{array}{l}6 \text { months } \\
\text { prvalue }\end{array}$ & $\begin{array}{l}12 \text { months } \\
\text { p-value }\end{array}$ & $\begin{array}{l}6 \text { months } \\
8(95 \% a)\end{array}$ & $\begin{array}{l}12 \text { months } \\
\mathrm{B}(95 \% \mathrm{Cl})\end{array}$ \\
\hline & \multicolumn{2}{|c|}{ Interactions with time } & \multicolumn{2}{|c|}{ Stratified analyses: evolution over time (months } \\
\hline \multicolumn{5}{|c|}{ ( } \\
\hline EROACPA- & 0.481 & 0.551 & $\cdot 0.24(-0.27 ;-0.22)$ & $-0.11(-0.12 ;-0.10)$ \\
\hline Erot ACPA. & 0.001 & $<0.001$ & $-0.30(-0.34 ;-0.26)$ & $-0.14(-0.16 ;-0.12)$ \\
\hline Ero-ACPAt & Ref & Ref & $-0.24(-0.25 ;-0.22)$ & $-0.11(-0.11 ;-0.099)$ \\
\hline Erot ACPAt & $<0.001$ & $<0.001$ & $-0.30(-0.32 ;-0.29)$ & $-0.12(-0.13 ;-0.12)$ \\
\hline \multicolumn{5}{|l|}{ HAQ } \\
\hline ERO-ACPA- & 0.035 & 0.121 & $-0.081(-0.096 ;-0.065)$ & $-0.034(-0.040 ;-0.027)$ \\
\hline Erot ACPA. & 0.072 & 0.034 & $-0.084(-0.10 ; \cdot 0.064)$ & $-0.038(-0.047 ;-0.029)$ \\
\hline Ero-ACPA+ & Ref & Ref & $-0.062(-0.072 ;-0.053)$ & $-0.027(-0.031 ;-0.023)$ \\
\hline Erot ACPA+ & $<0.001$ & 0.047 & $-0.086(-0.095 ;-0.078)$ & $-0.033(-0.037 ;-0.029)$ \\
\hline $\begin{array}{l}\text { "Results stem } \\
\text { exchangeabl } \\
\text { and country. } \\
\text { case, per mo } \\
\text { sp-values are } \\
\text { statisticallys } \\
\text { is shown for }\end{array}$ & vn for the & irmixed $\mathrm{m}$ & $\begin{array}{l}\text { smoking, symptom dur } \\
\text { f change in the out come } \\
\text { le chained equations }(40 \\
\text { sions/ACPA and time in } \\
\text { gender and the evolutio }\end{array}$ & $\begin{array}{l}\text { and slope and } \\
\text { on, BMI, initial medication } \\
\text { r unit of time, in this } \\
\text { cles). } \\
\text { ths. In the presence of a } \\
\text { f DAS and HAQ over time }\end{array}$ \\
\hline
\end{tabular}

Disclosure of Interests: Sytske Anne Bergstra Grant/research support from: Bristol-Myers Squibb provided funding for the completion of this 